\title{
PHARMACOLOGICAL ACTIVITY OF ULVA LACTUCA POLYPHENOLS FRACTION: CARDIOPROTECTIVE AND ANTIOXIDANT ACTIVITIES AGAINST ISOPROTERENOL-INDUCED MYOCARDIAL INFARCTION IN RATS
}

\author{
RAVINDRAN NT*, MOHAMED SADIQ A \\ Department of Biochemistry, Adhiparasakthi College of Arts and Science (Autonomous), G.B. Nagar, Kalavai, Tamil Nadu, India. \\ Email: ntraveendiran@gmail.com
}

Received: 20 June 2019, Revised and Accepted: 13 July 2019

\begin{abstract}
Objective: The objective of this study is to assess the activity of Ulva lactuca polyphenols fraction in protecting the myocardial infarction induced by a high dose of isoproterenol.

Methods: This study was carried out using Wistar albino rats divided into six groups. Group 1 was the normal group. Groups 2, 3, 4, 5, and 6 received isoproterenol ( $85 \mathrm{mg} / \mathrm{kg})$ i.p. twice at an interval of $24 \mathrm{~h}$ on the $14^{\text {th }}$ and $15^{\text {th }}$ day. In addition to isoproterenol, Group 3 received verapamil ( $\left.5 \mu \mathrm{mol} / \mathrm{kg}\right)$ as a single dose intravenously on the $14^{\text {th }}$ day $10 \mathrm{~min}$ before isoproterenol and Groups 4, 5, and 6 received $U$. lactuca polyphenols fraction at the doses of 50,100, and $200 \mathrm{mg} / \mathrm{kg}$, respectively, for 14 days. On the $16^{\text {th }}$ day, serum and heart samples were harvested from the animals and the cardioprotective and antioxidant activities were assessed by studying the levels of cardiac functional heart marker enzymes, lipid profile, reduced glutathione, and antioxidant enzymes.
\end{abstract}

Results: $U$. lactuca polyphenols fraction, at the tested doses, restored the levels of all serum markers and enzymes (aspartate aminotransferase, alanine aminotransferase, creatine phosphokinase, lactate dehydrogenase, cholesterol, triglycerides, and reduced glutathione) and heart homogenate antioxidant markers (reduced glutathione, superoxide dismutase, catalase, and glutathione peroxidase) significantly, in dose-dependent manner.

Conclusion: This study suggests that $U$. lactuca polyphenols fraction has a cardioprotective effect against isoproterenol-induced myocardial infarction and possess antioxidant activities.

Keywords: Cardioprotective activity, Antioxidant activity, Isoproterenol, Marine alga, Edible alga, Ulva lactuca, Polyphenols fraction.

(C) 2019 The Authors. Published by Innovare Academic Sciences Pvt Ltd. This is an open access article under the CC BY license (http://creativecommons. org/licenses/by/4. 0/) DOI: http://dx.doi.org/10.22159/ajpcr.2019.v12i9.34629

\section{INTRODUCTION}

Cardiovascular diseases are presently one of the major causes of disability and mortality in both economically well-developed and developing countries [1]. Cardiovascular diseases are the major cause of 17.1 million fatalities each year and it will reach up to 20 million in 2020 [2]. Isoprenaline, a synthetic catecholamine has a lethal effect on the myocardium. Among the diverse mechanisms proposed to explain isoprenaline-induced cardiac damage, generation of highly cytotoxic free radicals through auto-oxidation of catecholamines has been implicated as one of the important contributing factors [3].

At present, available cardioprotective drugs have been associated with a number of side effects and are very costly. Some safe and cost-effective medicinal plants have been indicated for their cardioprotective effects due to their chemical composition [4]. The medicines currently used to treat myocardial infarction have numerous side effects. Dietary factors play a crucial role in the development of different human diseases including cardiovascular diseases. Common conviction that herbal formulations are safer than modern drugs has led to grow the use of herbal preparations. The World Health Organization (WHO) estimates that $80 \%$ of the total world's population presently use medicines of herbal origin for primary health care [5]. Hence, the WHO has recommended the use of herbal medicines as an alternative medicine, especially in developing countries [6].

Since the 1970s, more than 21,855 structurally different, bioactive natural products with an astonishing array of biological activities have been discovered from marine microbes, algae, and invertebrates [7].
Although the ocean covers more than $70 \%$ of the earth's surface, we only utilize less than $10 \%$ of the total ocean area [8]. In particular, many marine organisms survive in complex habitats exposed to extreme conditions and in adapting to new environmental surroundings, they generate a wide variety of secondary metabolites which cannot be found in other organisms. Moreover, in view of its great taxonomic diversity, investigations related to the search for new bioactive compounds from the marine environment can be viewed as an almost limitless field. In addition, since the biological productivity of terrestrial ecosystems has also perhaps reached what it can achieve; the marine biodiversity of the ocean can be anticipated to yield new therapeutic agents [9].

The green marine alga Ulva lactuca, commonly known as sea lettuce, has long been used as food and as a traditional medicinal agent to treat helminthic infections, fever, urinary diseases, and dropsy [10]. U. lactuca is rich in flavonoids and has potent antioxidant properties [11]. The hepatoprotective nature of $U$. lactuca against liver injury induced by D-galactosamine/ endotoxin in rats has been established [12]. U. lactuca has also been shown to have potent hypocholesterolemic and antioxidant effects [13], antibacterial activity [14], nephroprotective activity [15], neuroprotective activity [16], alpha-amylase and alpha-glucosidase inhibitory activity [17], and hepatoprotective and antioxidant activities [18].

In view of these reports, the present investigation has been undertaken to evaluate the cardioprotective and antioxidant activities of the polyphenols fraction of $U$. lactuca against isoproterenol-induced myocardial infarction in rats. Marine alga U. lactuca was selected for the present study as it is an edible marine alga, easily available in the Gulf of Mannar Coast of Mandapam. 


\section{METHODS}

Collection of marine algae sample

Fresh marine alga $U$. lactuca was collected from the intertidal regions of the Mandapam coast of Gulf of Mannar. The taxonomic identification of species was done using standard literature and taxonomic keys. The alga was identified and authenticated by the Principal Scientist, Central Salt and Marine Chemical Research Institute, Mandapam Camp. The collected samples were cleaned well with the seawater until unnecessary impurities, adhering sand particles, and extraneous matter such as epiphytes, pebbles, and shells were removed and it was brought to the laboratory in sterile plastic bags containing seawater to prevent evaporation. It was subsequently washed thoroughly with tap water and distilled water to remove the surface salty materials. It was air-dried for 1 week and later ground in an electric mixer. The powdered samples were subsequently stored in the refrigerator for future use.

\section{Extraction of polyphenols fraction from $U$. lactuca}

The powdered samples were then extracted with $80 \%$ ethanol for $24 \mathrm{~h}$ under continuous shake at $20^{\circ} \mathrm{C}$. The extracts were then concentrated in a rotary evaporator under reduced pressure at $40^{\circ} \mathrm{C}$ [19]. The solid mass obtained was stored at $4^{\circ} \mathrm{C}$. At the time of administration to the rats, the polyphenols fraction was dissolved in distilled water to required concentration.

\section{Experimental animals}

Male Wistar albino rats weighing 150-200 g were used in the study. The animals were maintained in well ventilated room with $12: 12$ light/dark cycle, $24 \pm 2^{\circ} \mathrm{C}$ temperature, and $30-70 \%$ relative humidity, in polypropylene cages. Standard rat rodent pellets (M/s. Hindustan Lever Ltd., Mumbai) and water were provided ad libitum. Animals were acclimatized to the laboratory conditions 1 week before the initiation of the study. The study was approved by the Institutional Animal Ethical Committee (IAEC) constituted for the purpose of CPCSEA (IAEC/APCAS/01/2015/01).

Acute oral toxicity performed according to OECD-423 guidelines [20], has already been referred to in our earlier study [20]. U. lactuca polyphenols fraction did not produce any mortality even at the highest dose (2000 mg/kg) employed, and hence, U. lactuca polyphenols fraction was considered to be safe for further pharmacological screening. Three submaximal doses $(50,100$, and $200 \mathrm{mg} / \mathrm{kg})$ were employed for further pharmacological investigations.

\section{Induction of myocardial infarction}

Myocardial infarction was induced in rats by dissolving isoproterenol in normal saline and injecting intraperitoneally to rats $(85 \mathrm{mg} / \mathrm{kg}$ body weight) at an interval of $24 \mathrm{~h}$ for 2 days [21].

\section{Experimental design}

Male Wistar albino rats (male) weighing between 150 and 200 g were divided into six groups of six animals each. The weight range of the animals was equally distributed throughout the groups.

- Group 1: Control rats received distilled water orally for 7 days.

- Group 2: Treated with isoproterenol (85 mg/kg) i.p. twice at an interval of $24 \mathrm{~h}$ on the $14^{\text {th }}$ and $15^{\text {th }}$ day.

- Group 3: Treated with verapamil ( $5 \mu \mathrm{mol} / \mathrm{kg})$ as a single dose intravenously on the $14^{\text {th }}$ day, followed after 10 min by isoproterenol $\left(85 \mathrm{mg} / \mathrm{kg}\right.$ ) i.p. twice at an interval of $24 \mathrm{~h}$ on the $14^{\text {th }}$ and $15^{\text {th }}$ day.

- Group 4: Treated with U. lactuca polyphenols fraction $(50 \mathrm{mg} / \mathrm{kg})$ dissolved in water for 14 days, followed by isoproterenol $(85 \mathrm{mg} / \mathrm{kg})$ i.p. twice at an interval of $24 \mathrm{~h}$ on the $14^{\text {th }}$ and $15^{\text {th }}$ day.

- Group 5: Treated with U. lactuca polyphenols fraction $(100 \mathrm{mg} / \mathrm{kg})$ dissolved in water for 14 days, followed by isoproterenol $(85 \mathrm{mg} / \mathrm{kg})$ i.p. twice at an interval of $24 \mathrm{~h}$ on the $14^{\text {th }}$ and $15^{\text {th }}$ day.

- Group 6: Treated with U. lactuca polyphenols fraction $(200 \mathrm{mg} / \mathrm{kg})$ dissolved in water for 14 days, followed by isoproterenol ( $85 \mathrm{mg} / \mathrm{kg})$ i.p. twice at an interval of $24 \mathrm{~h}$ on the $14^{\text {th }}$ and $15^{\text {th }}$ day.
Animals were kept starved overnight on the $15^{\text {th }}$ day. The next day, all the animals were sacrificed under light ether anesthesia. Blood was collected by direct cardiac puncture into sterilized dry centrifuge tubes and allowed to coagulate for $30 \mathrm{~min}$ at $37^{\circ} \mathrm{C}$. The clear serum was separated at $2500 \mathrm{rpm}$ for $10 \mathrm{~min}$ and subjected to various biochemical estimations. Hundred milligram of heart issue from each rat was used for antioxidant study.

\section{Biochemical estimations}

The separated sera were subjected to biochemical estimation of different parameters such as alanine aminotransferase (ALT), aspartate aminotransferase (AST) [22], creatine phosphokinase (CPK) [23], lactate dehydrogenase (LDH) [24], cholesterol [25], triglycerides [26], and reduced glutathione [27].

\section{The antioxidant status}

One hundred milligram of heart tissue was weighed and homogenate was prepared in $10 \mathrm{ml}$ Tris hydrochloric acid buffer $(0.5 \mathrm{M}$; pH 7.4) at $4^{\circ} \mathrm{C}$. The homogenate was centrifuged and the supernatant was used for the estimation of reduced glutathione [27] and assay of antioxidant enzymes such as superoxide dismutase [28], catalase [29], and glutathione peroxidase [30].

\section{Statistical analysis}

One-way analysis of variance followed by Dunnett's t-test was applied for determining the statistical significance of difference between experimental groups. $\mathrm{p}<0.05$ was considered to be statistically significant.

\section{RESULTS AND DISCUSSION}

Myocardium contains an abundant concentration of diagnostic marker enzymes of myocardial infarction and once metabolically damaged, it releases its contents into the extracellular fluid [31]. In our study, isoproterenol is used to induce myocardial damage. It is a synthetic catecholamine and beta-adrenergic agonist, and has been found to cause a severe stress in the myocardium resulting in infarct like necrosis of the heart muscle cells and is also well known to generate free radicals and stimulate lipid peroxidation, which may be a causative factor for irreversible damage to the myocardial membrane in experimental myocardial infarction [32].

The rats were pre-treated with $U$. lactuca polyphenols fraction for 14 days before isoproterenol administration. Estimating the activities of serum marker enzymes such as AST, ALT, CPK, and LDH are a tool for the assessment of the cardiac function. Isoproterenol is well known cardiotoxic agent due to its ability to destruct myocardial cells. As a result of this, cytosolic enzymes such as LDH, transaminases (ALT and AST), and CPK were released into the bloodstream and serve as diagnostic markers of myocardial tissue damage [33]. The amount of these cellular enzymes present in blood reflects the alterations in plasma membrane integrity and/or permeability.

There was a significant increase $(\mathrm{p}<0.01)$ in the levels of AST, ALT, CPK, LDH, total cholesterol, and triglycerides as well as a significant decrease $(p<0.01)$ in plasma reduced glutathione in isoproterenoltreated animals from those of the control group. Administration of U. lactuca polyphenols fraction ( 50,100 , and $200 \mathrm{mg} / \mathrm{kg}$ ) brought down the levels of AST, ALT, CPK, LDH, total cholesterol, and triglycerides to near-normal levels, in a dose-dependent manner $(\mathrm{p}<0.01)$. The levels of plasma reduced glutathione were increased significantly by the administration of $U$. lactuca polyphenols fraction in a dose-dependent manner. Verapamil, the reference drug restored the altered levels of enzymes significantly $(\mathrm{p}<0.01)$ (Table 1$)$

Increased activities of CPK, transaminases, and LDH in serum, "the diagnostic markers," were due to the leakage of these enzymes as a result of necrosis induced by isoproterenol ( $\beta$-adrenergic stimulant) in rats [34]. CPK is a muscle-specific enzyme mainly for heart and brain; therefore, its increase in serum is the result of myocarditis, cardiac insufficiency, arrhythmias, and myocardial infarction [35]. 
Table 1: Effect of Ulva lactuca polyphenols fraction on serum marker enzymes and reduced glutathione

\begin{tabular}{|c|c|c|c|c|c|c|}
\hline Parameters & Group 1 & Group 2 & Group 3 & Group 4 & Group 5 & Group 6 \\
\hline AST (IU/L) & $83.50 \pm 3.48$ & $221.33 \pm 9.39^{a *}$ & $88.50 \pm 4.07^{\mathrm{b} *}$ & $105.67 \pm 4.87^{\mathrm{b} *}$ & $98.33 \pm 4.68^{\mathrm{b} *}$ & $89.33 \pm 4.24^{\mathrm{b} *}$ \\
\hline ALT (IU/L) & $47.50 \pm 2.32$ & $110.50 \pm 5.21^{\mathrm{a} *}$ & $51.50 \pm 2.55^{\mathrm{b} *}$ & $67.50 \pm 3.17^{\mathrm{b} *}$ & $62.83 \pm 2.50^{\mathrm{b} *}$ & $57.17 \pm 2.18^{\mathrm{b} *}$ \\
\hline CPK (IU/L) & $189.33 \pm 6.60$ & $381.83 \pm 12.28^{\mathrm{a} *}$ & $190.17 \pm 6.70^{\mathrm{b} *}$ & $245.33 \pm 10.25^{\mathrm{b} *}$ & $228.17 \pm 9.76^{\mathrm{b} *}$ & $207.50 \pm 8.98^{\mathrm{b} *}$ \\
\hline LDH (IU/L) & $112.00 \pm 5.94$ & $196.67 \pm 9.48^{\mathrm{a} *}$ & $117.17 \pm 5.38^{\mathrm{b} *}$ & $143.17 \pm 6.70^{\mathrm{b} *}$ & $133.17 \pm 6.27^{\mathrm{b} *}$ & $121.17 \pm 5.25^{\mathrm{b} *}$ \\
\hline Total cholesterol (g/dL) & $97.00 \pm 4.70$ & $162.00 \pm 7.34^{\mathrm{a} *}$ & $101.83 \pm 4.82^{\mathrm{b} *}$ & $126.00 \pm 5.83^{\mathrm{b} *}$ & $117.17 \pm 5.25^{\mathrm{b} *}$ & $106.50 \pm 4.98^{\mathrm{b} *}$ \\
\hline Triglycerides (g/dL) & $91.00 \pm 3.55$ & $196.50 \pm 8.87^{a *}$ & $96.50 \pm 4.96^{\mathrm{b} *}$ & $116.33 \pm 5.61^{\mathrm{b} *}$ & $108.17 \pm 5.33^{\mathrm{b} *}$ & $98.33 \pm 4.58^{\mathrm{b} *}$ \\
\hline Reduced glutathione (mg/dL) & $30.12 \pm 1.43$ & $17.43 \pm 0.78^{\mathrm{a} *}$ & $29.33 \pm 1.41^{\mathrm{b} *}$ & $22.87 \pm 1.09^{\mathrm{b} *}$ & $24.58 \pm 1.31^{\mathrm{b} *}$ & $27.32 \pm 1.32^{\mathrm{b} *}$ \\
\hline
\end{tabular}

Group A - Control, Group B - ISO, Group C - ISO+Verapamil, Group D - ISO+ULPF 50 mg/kg, Group E - ISO+ULPF 100 mg/kg, Group F - ISO+ULPF 200 mg/kg. ISO: Isoproterenol, ULPF: Ulva lactuca polyphenols fraction. The observations are given as Mean \pm SEM, $\mathrm{n}=6$; ${ }^{*} \mathrm{p}<0.01$, a: Group I versus Group II, b: Group II versus Groups III, IV, V, and VI, AST: Aspartate aminotransferase, ALT: Alanine aminotransferase, CPK: Creatine phosphokinase, LDH: Lactate dehydrogenase

Table 2: Effect of Ulva lactuca polyphenols fraction on heart homogenate reduced glutathione and antioxidant enzymes

\begin{tabular}{|c|c|c|c|c|c|c|}
\hline Parameters & Group 1 & Group 2 & Group 3 & Group 4 & Group 5 & Group 6 \\
\hline $\begin{array}{l}\text { Heart reduced } \\
\text { glutathione (mg/100 g wet tissue) }\end{array}$ & $47.18 \pm 2.34$ & $22.87 \pm 1.10^{\mathrm{a} *}$ & $46.05 \pm 2.27^{\mathrm{b} *}$ & $36.30 \pm 1.65^{\mathrm{b} *}$ & $39.02 \pm 1.87^{\mathrm{b} *}$ & $43.35 \pm 1.99^{\mathrm{b} *}$ \\
\hline${ }^{2}$ Catalase & $61.85 \pm 2.66$ & $32.52 \pm 1.76^{\mathrm{a} *}$ & $59.37 \pm 2.59^{\mathrm{b} *}$ & $47.27 \pm 1.98^{\mathrm{b} *}$ & $50.82 \pm 2.35^{\mathrm{b} *}$ & $56.45 \pm 2.58^{\mathrm{b} *}$ \\
\hline${ }^{3}$ Glutathione peroxidase & $8.45 \pm 0.39$ & $3.92 \pm 0.28^{\mathrm{a} *}$ & $8.04 \pm 0.35^{\mathrm{b} *}$ & $6.18 \pm 0.28^{\mathrm{b} *}$ & $6.65 \pm 0.32^{\mathrm{b} *}$ & $7.38 \pm 0.36^{\mathrm{b} *}$ \\
\hline
\end{tabular}

Group A - Control, Group B - ISO, Group C - ISO+Verapamil, Group D - ISO+ULPF 50 mg $/ \mathrm{kg}$, Group E - ISO+ULPF 100 mg $/ \mathrm{kg}$, Group F - ISO+ULPF 200 mg/kg,

ISO: Isoproterenol, ULPF: Ulva lactuca polyphenols fraction, ${ }^{1}$ Superoixde dismutase is expressed as $50 \%$ inhibition of epinephrine auto-oxidation/min/mg protein. ${ }^{2}$ Catalase is expressed as $\mu$ moles of $\mathrm{H}_{2} \mathrm{O}_{2}$ decomposed $/ \mathrm{min} / \mathrm{mg}$ protein. ${ }^{3}$ Glutathione peroxidase is expressed as $\mu$ moles of glutathione oxidized/min/mg protein. The observations are given as Mean $\pm \mathrm{SEM}, \mathrm{n}=6$; ${ }^{\mathrm{p}}<0.01$, a: Group I versus Group II, b: Group II versus Groups III, IV, V, and VI

Reduced activities of the antioxidant enzymes, superoxide dismutase, catalase, and glutathione peroxidase, observed in the heart homogenate of isoproterenol-treated rats, indicate the extensive myocardial damage induced by the cardiotoxin $(\mathrm{p}<0.01)$. The tendency of these enzymes to return to near normalcy in $U$. lactuca polyphenols fraction administered groups $(50,100$, and $200 \mathrm{mg} / \mathrm{kg})$ in a dose-dependent manner is a clear indication of cardioprotective effect of $U$. lactuca polyphenols fraction extract through antioxidant mechanism $(\mathrm{p}<0.01)$ (Table 2).

Experimental and epidemiological studies indicate the involvement of oxidative stress in the pathogenesis and progression of many chronic diseases [36]. It is known that oxygen, essential for maintaining life, sometimes becomes toxic and results in the generation of most aggressive agents such as reactive oxygen species (ROS). The high reactivity of ROS may activate a host of disorders in the body resulting in tissue damage and necrosis in many instances [37]. The body has an effective mechanism to avoid and neutralize the free radical-induced damage. This is done through a set of endogenous antioxidant enzymes such as superoxide dismutase, catalase, and glutathione peroxidase. When the equilibrium between ROS production and antioxidant defense is lost, oxidative stress results, which through a series of events, deregulate the cellular functions, leading to various pathological conditions [38].

It is possible that natural antioxidants strengthen the endogenous antioxidant defense from ROS damage and restore the optimal equilibrium by neutralizing the reactive species. They are gaining enormous importance by virtue of their critical role in disease prevention.

\section{CONCLUSION}

It may be said that the polyphenols fraction of $U$. lactuca, commonly used as a food and as a traditional medicinal agent, has exhibited a cardioprotective effect against isoproterenol-induced cardiotoxicity and possessed antioxidant activities. U. lactuca is seaweed, but it is proven to possess immense potential by this study. Efforts are underway to isolate and purify the active principle involved in the cardioprotective efficacy of this marine alga.

\section{ACKNOWLEDGMENT}

The authors are grateful to the management of Adhiparasakthi College of Arts and Science (Autonomous), Kalavai, India, for providing the facilities.

\section{AUTHORS' CONTRIBUTIONS}

Ravindran N T designed study project and performed experiments. He was also engaged in manuscript editing and finalization. Mohamed Sadiq A designed study project, contributed to experiment finalization and implementation, manuscript editing, and finalization.

\section{CONFLICTS OF INTEREST}

The authors declare that they have no conflicts of interest.

\section{REFERENCES}

1. Tengattini S, Reiter RJ, Tan DX, Terron MP, Rodella LF, Rezzani R, et al. Cardiovascular diseases: Protective effects of melatonin. J Pineal Res 2008;44:16-25.

2. Upaganlawar A, Gandhi H, Balaram R. Isoproternol induced myocardial infarction; protective role of natural products. J Pharm Toxicol 2011;6:1-17.

3. Bafna PA, Balaraman R. Antioxidant activity of DHC-1, an herbal formulation, in experimentally-induced cardiac and renal damage. Phytother Res 2005;19:216-21.

4. Gauthaman K, Maulik M, Kumari R, Manchanda SC, Dinda AK, Maulik SK, et al. Effect of chronic treatment with bark of Terminalia arjuna: A study on the isolated ischemic-reperfused rat heart. J Ethnopharmacol 2001;75:197-201.

5. Calixto JB. Efficacy, safety, quality control, marketing and regulatory guidelines for herbal medicines (phytotherapeutic agents). Braz J Med Biol Res 2000;33:179-89.

6. World Health Organization. Launches of the First Global Strategy on the Traditional Medicine. Geneva, Switzerland: WHO Press Release; 2002.

7. Blunt JW, Copp BR, Munro MH, Northcote PT, Prinsep MR. Marine natural products. Nat Prod Rep 2012;29:144-222.

8. Schultes RE. The kingdom of plants. In: Thomson WA, editor, Medicines from the Earth. New York: Mc Graw-Hill Book Co.; 1978. p. 208.

9. Bugni TS, Ireland CM. Marine-derived fungi: A chemically and biologically diverse group of microorganisms. Nat Product Rep 2004;21;143-63.

10. Kim IH, Lee DG, Lee SH, Ha JM, Ha BJ, Kim BJ, et al. Antibacterial activity of Ulva lactuca against Methicillin-resistant staphylococcus aureus (MRSH). Biotechnol Bioprocess Eng 2007;12:579-82.

11. Meenakshi S, Gnanambigai DM, Mozhi ST, Arumugam M, Balasubramanian T. Total flavanoid and in vitro antioxidant activity of two seaweeds of Rameshwaram coast. Global J Pharmacol 2009;3:59-62. 
12. Sathivel A, Raghavendran HR, Devaki T. Hepatoprotective nature of seaweeds (Ulva lactuca/Gracilaria edulis) against liver injury induced by D-Galactosamine/endotoxin in rats. Seaweed Res Utlin 2003;25:109-11.

13. Hassan S, El-Twab SA, Hetta M, Mahmoud B. Improvement of lipid profile and antioxidant of hypercholesterolemic albino rats by polysaccharides extracted from the green alga Ulva lactuca Linnaeus. Saudi J Biol Sci 2011;18:333-40.

14. Pushparaj A, Raubbin RS, Balasankar T. Antibacterial activity of Kappaphycus alvarezii and Ulva lactuca extracts against humanpathogenic bacteria. Int J Curr Microbiol Appl Sci 2014;3:432-6.

15. Mahmoud HM, Hussein UL. Suppression of N-nitrosodiethylamine induced oxidative renal toxicity by sulphatedpolysaccharide and aqueous extract of Ulva lactuca in rats. Int J Pharm Pharm Sci 2014;6:248-53.

16. Suganthy N, Pandian SK, Devi KP. Neuroprotective effect of seaweeds inhabiting South Indian coastal area (Hare Island, Gulf of Mannar Marine Biosphere Reserve): Cholinesterase inhibitory effect of Hypnea valentiae and Ulva reticulata. Neurosci Lett 2010;468:216-9.

17. Reka P, Banu AT, Seethalakshmi M. Alpha amylase and alpha glucosidase inhibition activity of selected edible seaweeds from South coast area of India. Int J Pharm Pharm Sci 2017;9:64-8.

18. Ravindran NT, Sadiq AM. Pharmacological activity of Ulva lactuca polyphenols fraction Hepatoprotective and antioxidant activities against paracetamol-induced liver damage in rats. Asian J Pharm Clin Res 2019;12:55-8.

19. Heo SJ, Cha SH, Lee KW, Jeon YJ. Antioxidant activities of red algae from Jeju Island. Algae 2006;21:149-56.

20. Ecobichon DJ. The basis of Toxicology Testing. $2^{\text {nd }}$ ed. New York: CRC Press; 1997. p. 43-60.

21. Rajadurai M, Prince PS. Preventive effect of naringin on lipids, lipoproteins and lipid metabolic enzymes in isoproterenol-induced myocardial infarction in Wistar rats. J Biochem Mol Toxicol 2006;20:191-7.

22. Reitman S, Frankel AS. A colorimetric method for the determination of serum glutamic oxaloacetic and glutamate pyruvate transaminase. Am J Clin Path 1957;28:53-6.

23. Okinaka S, Kumaggai H, Ebashi S, Sugita H, Momoi H, Toyokura Y, et al. Serum creatine phosphokinase. Activity in progressive muscular dystrophy and neuromuscular diseases. Arch Neurol 1961;4:520-5.

24. King J. The hydrolase and alkaline phosphatase. In: Practical Clinical Enzymology. London: Nostrand Co., Ltd.; 1965. p. 191
25. Parekh AC, Jung DH. Cholesterol determination with ferric acetateuranium acetate and sulfuric acid-ferrous sulfate reagents. Anal Chem 1970;42:1423-7.

26. Foster LB, Dunn RT. Stable reagents for determination of serum triglycerides by colorimetric Hantzsch condensation method. Clin Chem 1973;18:338-40.

27. Moron MS, Depierre JN, Mannervik B. Levels of glutathione, glutathione reductase and glutathione-S-transferase activity in rat lung and liver. Biochim Biophys Acta 1979;582:67-78.

28. Misra HP, Fridovich I. The role of superoxide anion in the autoxidation of epinephrine and a simple assay for superoxide dismutase. J Biol Chem 1972;247:3170-5.

29. Takahara S, Hamilton BH, Neel JV, Kobara TY, Ogura Y, Nishimiua ET. Hypocatalasemia, a new genetic carrier state. J Clin Invest 1960;39:610-9.

30. Rortruck JT, Pope AL, Ganther HE, Swanson AB. Selenium: Biochemical roles as a component of glutathione peroxidase. Science 1973;179:588-90.

31. Suchalata S, Devi CS. Protective effect of Terminalia chebula against experimental myocardial injury induced by isoproterenol. Ind J Exp Biol 2004;42:174-8

32. Kumar HS, Anandan R, Devaki T, Kumar MS. Cardioprotective effects of Picrorrhiza kurrora against isoproterenol induced myocardial stress in rats. Fitoterapia 2001;72:402-5.

33. Farvin KH, Anandan R, Kumar SH, Shiny KS, Sankar TV, Thankappan TK. Effect of squalene on tissue defense system in isoproterenol-induced myocardial infarction in rats. Pharmacol Res 2004;50:231-6.

34. Bergstrom K, Sawa U. Improved diagnosis of acute myocardial infarction by frequent serum enzyme determinations, Acta Med Scand 1973;193:515-23.

35. Okinaka S, Kumogai H, Ebashi S, Sugita H, Momoi H, Toyukura Y, et al. Serum creatine phosphokinase activity in progressive muscular dystrophy and neuromuscular diseases. J Biol Chem 1961;4:520-5.

36. Tewari S, Gupta V, Bhattacharya S. Comparative study of antioxidant potential of tea with and without additives. Indian J Physiol Pharmacol 2000;44:215-9.

37. Prasad VS, Venkatachalam SR, Chander R, Thomas P. Dietary antioxidantsnatural defense against disease. Aryavaidyan 1999;12:149-58.

38. Bandyopadhyay U, Das D, Banerjee KR. Reactive oxygen species: Oxidative damage and pathogenesis. Curr Sci 1999;77:658-66. 